\title{
Derivation and the Derivational Space in Phraseology as a Problem of the Language Contemporary Development
}

\author{
Elena Nicolayevna Ermakova \\ Natalia Nikolaevna Zolnikova \\ Guzel Chakhvarovna Faizullina \\ Milyausha Sakhretdinovna Khasanova \\ Tatiana Nikolaevna Khlyzova \\ Tobolsk branch of Tyumen State University \\ Email: ermakova25@yandex.ru
}

\section{Doi:10.5901/mjss.2015.v6n3s6p335}

\begin{abstract}
The Modern society undergoes considerable social, political, economic and other transformations that influence the language. Researchers note the changes in the language under the migratory processes influence (Ryazantsev et all, 2014; Karabulatova, Polivara 2013; Karabulatova, Sayfulina, Ahmetova, 2013; Sayfulina, Karabulatova, 2014; Gilazov et all, 2015). Using the language as the means of communication, the society creates the conditions for some or other language changes (Skandera 2007; Karabulatova, Polivara 2015; Karabulatova 2013; Nikolaev, 2006). One of the ways of enrichment of the language phrasicon is formation of phraseological units on the basis of already existing in the language phraseological units. Today the question of present interest concerns the paradigm "a productive phraseological unit $\rightarrow$ a derived phraseological unit" development, but up to the present moment the problem of the "secondary" phrase -formation remains low-developed and that's why extremely contraversial (Ermakova, 2008; Karabulatova 2014; Lomakina 2014). Meanwhile the subject area value concerning the phraseological system development is obvious: learning the derivational potential of phraseological veils the secret of dynamic processes in the phraseological structure of Russian.
\end{abstract}

Keywords: phraseology, derivation, Russian, ethnography of speech

\section{Introduction}

Traditionally the phraseology was considered as a study of "fixed word- combinations ", and a phraseological unit was perceived as a fixed, statical concept that does not change (Cowie, 2001; Carter, 2004). Today there is a great need of determination of the internal phrase-formation mechanisms, common factors and reasons of this process because phraseological units are the base for great number of derived phraseological units formation, and this process is universal (Cowie, 2001; Skandera 2007; Zamaletdinov et all 2014; Karabulatova, Sayfulina, 2015; Sayfulina, Karabulatova, 2014). In turn, the occurrence of new phraseological formations promotes the regular enrichment of the phraseological modern language structure (Karabulatova 2014; Carter, 2004).

The occurrence of new phraseological units in the language is considered as a process of phrase-formation. The subject of phrase-formation study is types, models of phraseological units and common factors of their formation. Ronald Carter was right talking about the fact that the already existing phraseological units development is close connected with phrase-formation. This derivational and system, "secondary" phrase-formation is connected with the internal phraseological units development caused by their functioning in the system of language (Carter 2004: 43). So, researchers' interest to the national and cultural features of the languages phraseological structure and their variants increases proportionally to understanding by language collectives their identity (Karabulatova \& Sayfulina, 2015; Sayfulina, Karabulatova, 2014; Sayfulina et all, 2013; Karabulatova et all, 2015), and, as a result, to aspiration to keep it from the globalization processes influence (Karabulatova and Zinchenko, 2014; Karabulatova, Ermakova \& Chiganova, 2014; Ryazantsev et all, 2014).

The phraseological structure of the national variant comprises phraseological units (based both on the basis of phraseological units of the nationwide language and without it) that brightly reflect the linguistic world- image of native 
speakers.

\section{Materials and Methods}

This work tries to study the derivational correlation of productive and derived phraseological units such as: бить в грудь $\rightarrow$ биение в грудь $\rightarrow$ битье в грудь; водить за нос $\rightarrow$ вождение за нос; втаптывать в грязь $\rightarrow$ втаптывание в грязь; варить суп из топора $\rightarrow$ варка супа из топора;; делить шкуру неубитого медведя $\rightarrow$ деление шкуры неубитого медведя, дележ шкуры неубитого медведя, дележка шкуры неубитого медведя; копаться в грязном белье $\rightarrow$ копание в грязном белье, etc.

The diachronic processes because of the fact that the question is very serious demand the individual research. The phrase-formation and the dynamic area of the language system are characterized by following peculiar features: ways and means that promote the phrase-formation; specific character of word collocation; conditions for the phraseformation process realization, thus the phrase-formation mechanisms appear. Specific character of this process dictates also occurrence of its system of terms.

The data of word-formation dictionaries of the Russian language, of V.I. Dahl's Phraseological Dictionary of the Living Great Russian Language were used as materials. These language entries were analyzed in the context of the made associative experiment that showed vitality of studied phraseological units.

The dynamic language development caused one more way activation - the internal phrase-formation (or the secondary transposition). Under the internal formation we understand the new phraseological unit formation on the basis of the phraseological unit that a ready exists in the language (Ermakova 2008: 7). The special feature of studying of the internal formation ways is that derived phraseological units have not to be considered as separately taken phraseology units, but in their relations to the corresponding productive phraseological units. The comparative analysis of phraseological new formations and their base, the productive phraseological units allows estimating the internal phraseformation. In case when a derived phraseological unit gains new individual meaning and new morphological and grammatical features, unlike a productive one, it is possible to claim that a new phraseological unit has occurred in language and speech. There is a need to put in a proper order the terms used for denotation of different ways of the internal phrase-formation.

In scientific researches phraseological units - derivatives are often considered as variants of the same unit, thus, depending on the transformation nature, scientists mark different types of phraseological variants: phonetic, morphological, syntactic, lexical, quantitative, variants of the mixed type, etc. But the complication of the results of phraseological units transformation process of makes us have another opinion: "However researches show that different alternative phraseological units transformations have certain borders, the process out of which breaks the variation sphere and results the phraseological derivation" (Avaliani, 1975: 8). Especially bright this process is observed in modeling of the Eurasian language personality where there is a mixture of styles, languages and cultures (Karabulatova 2013: 754).

Understanding the variation as an idea of bright ways of expression of any language essence as about its modification, great number of variants or of the deviation from any form, we consider that in phraseology it is necessary to understand different variants of the same unit without violation of sameness of these units. Such understanding allows us to assume that phraseological units that are the subject of our research, cannot be qualified as variants.

In present work we consider the most productive way of the internal phrase-formation that is derivation (from lat. derivatio - assignation; formation). Linguists call this process differently: the morphological derivation (Zhukov A.V.), derivational and systematic, "the secondary phrase-formation" (V. N. Teliya), the secondary phraseological derivation (Avaliani Yu.Yu. \& Emirova A.M.); and units that have appeared in the phrase-formation system development received the following names: transforms of the corresponding verbal and substantive phraseological combinations (Smerchko E.V.), the verbal complex from phraseology, the derivative formation from phraseology, the substantive verbal derivative (Bushui A.M.), the syntactic variation of phraseological units (Gvozdarev Yu.A.).

The analysis of the researches devoted to the phrase-formation problem in the sphere of phraseology allowed making a conclusion that phraseology of the modern Russian language is dynamic, constantly developing system, and the phrase-forming is a difficult language phenomenon that is characterized its own ways, regularities and results. The internal phrase-formation is carried out by several ways: derivation, intraphraseological homonymy, explication, implication and, partially, contanimation. 


\section{Results}

We will present our point of view about the sense of the concept "derivation" concerning phraseology and phraseological units. In modern linguistics the derivation as the way of the phrase-formation is understood differently: in the narrow sense the derivation is a deductibility of one from another according to the formal means, and in the wide sense - without paying attention to a formant. Such understanding cannot cause great disagreements and does not allow revealing the derivation consequence, so, does not allow systematizing and describing the process results. So, for example, the initial PU component structure reduction or its compression (проливать крокодиловы слезы - проливать слезы); derivation is also the opposite process to compression when expansion of a phraseological unit is observed in the structurally more difficult formation (грош цена - грош цена в базарный день) (Teliya, 1975: 54; Cowie, 2001: 87). Perhaps, it would be possible to agree with this point of view because, actually, as a result of the initial form reduction or compression(ellipsis, implication, compression, reduction of a number of components, on terminology of other authors) and as a result of expansion (explication, increase of a number of components) there is a unit formed on the basis of the phraseological unit that already exist in the language, differing by "its special distributive relations and other syntactic function". But the situation reflected in linguistic reference books explaining that the derivation is not only a new unit, formation but also the process which is followed formal (but not structural - E.E.) does not allow to agree with changes in unit. On the other hand, in scientific literature there are also supervision about the intraphraseological derivational processes which are carried out in the form of word-formation activity of some components at preservation of their initial image. It is considered that it reaches more differentiated expression of semantic-stylistic opportunities of PU in connection with its contextual conditions of use.

Materials of our card file show that only $7 \%$ of phraseological units-derivatives are formed by means of a zero suffix: запахло жареным $\rightarrow$ запах $\rightarrow$ жареного, ловить блох $\rightarrow$ ловля блох, выбирать/выбрать меньшее из зол $\rightarrow$ выбор меньшего из зол.

The impossibility to form the subject phraseological unit from the procedural is explained generally by two factors: dissonance of substantivized secondary formation and special character of the phraseological meaning that is not developing on the way of further abstraction.

The productive procedural phraseological units call an action, a state, subject and phraseological units, derivatives, name this action, process. Therefore, correlative procedural and subject phraseological units at the level of the logical concept are identical. The identity of the logical meaning of process in correlative phraseological units is supported by one nuclear seme, one conceptual point. And still in semantics of derivative subject phraseological units there is a predictable shift caused first of all by their all-categorical semantics. So, the subject phraseological units-derivatives are characterized by the high degree of abstractness and designate, as a rule, abstract concepts. Substantiv, being the main grammatical component of the subject phraseological units, continues to be influenced by semantic influence of the initial verb, it has only the most abstract process seme, names the process. The meaning of the abstract noun becomes the categorical meaning of new subject unit which is formed by a set of meanings of all components of a new phraseological unit. As a result the subject phraseological units have a general meaning of continuing action, but do not express the process result. Therefore, derivative units if to qualify them from the point of view of logical-semantic, are designation of actions, processes if to estimate them from the point of view of formal and grammatical, they are the subject phraseological units, names of actions.

\section{Discussion}

The diachronic phrase formation development is discussed in the works of Yu.Yu. Avaliani, Yu.A. Gvozdaryov, V.I.Zimin, V.V. Istomina, V.I. Kodukhov, M.M. Kopylenko, A.V. Kunin, V.M. Mokienko, M.F. Palevskaya, R.N. Popov, L.I. Royzenzon, G.A. Selivanov, V.N. Teliya, E.N.Tolikina and A.M. Emirova, et al. The scientists consider the appearance of phraseological units based on variable collocations as an external phrase formation.

A number of works consider units with the suffix -к- (дойная корова - дойная коров-к-а, как об стену горох как об стен-к-у горох) and units with the affectionate diminutive suffix (заблудшая овца - заблудшая ов-ечк-а, горя мало - гор-юшк-а мало, забубенная голова - забубенная голов-ушк-а), etc. as phraseological derivatives. If it would be separate lexemes with such suffixal transformations, we were able to speak about different words, about a productive word and a derived one, and, consequently, about a derivative. It is important to say that a phraseological unit being a separate unit has the more complex nature: a phraseological unit as a whole and not separate components is involved in derivational relations, and morphemic patterns (in phraseology this phenomenon is classified so) do not cause the changes in the phraseological meaning. Compare: both заблудшая овца and заблудшая овечка means a person who 
separated from his or her circle, society, family, etc., who lost his or her way; горя мало and горюшка мало is an assessment of indifference, neglect to smth., a lack of one's concern about smth.; both забубенной головой and забубенной головушкой define a reckless, dissolute fellow. The mentioned and other pairs of phraseological units have no differences in categorical or subcategorial meaning, therefore we are not able to speak about derivational relations among such phraseological units.

Certain studies consider such units as word-formation patterns: "...occasional words are found in word-formation patterns of phraseological units very often. It occurs when words with emotive suffixes substitute neutral words in the component structure of phraseological units: ... фрилькина грамота and фрилюшкина грамота, сердие екнуло and сердчишко екнуло" (Kolesnikova \& Popov, 1980: 11). We do not share this point of view. The word-formation patterns can be mentioned if we deal with the lexemes, but we consider the super-word - phraseological - units.

The morphemic changes in one of the components (no matter in the grammatically main or grammatically dependent one) like фриговый листок (лист, листик, листочек), год-другой (годок-другой), точь-в-точь (точка в точку), as we can see, do not allow to consider a derived phraseological unit as a derivative. These variants differ from each other only stylistically, because semantically, morphologically and syntactically these phraseological units are identical. Compare: Ох, изморился я, отцы ... Жарынь ... Кваску бы испить, Аграсрена Филипповна? ... - А ты ступай в кабинет ко мне, - предлагал Nicolas. -Tам найдешь, чем червяка заморить. (Mamin-Sibiryak. The Privalov Fortune) - Прихватив кое-что, чтобы, как говорится, червячка заморить, и выпив одну рюмочку водки, господин Голядкин уселся в креслах. (Dostoyevsky F., The Double) - A как, Пал Егорыч, насчет червячка заморить? - спрашивает Николай Стаматич, указывая глазами на водку. (Chekhov A. From childhood of A.P. Chekhov)

The analysis of the meaning and functioning of the mentioned correlative phraseological units suggests that such phraseological units do not enter into derivational relations with each other: they are semantically identical, define the same item, belong to the same semantic and grammatical class and have the same group and individual meaning. Therefore, there are no grounds to talk about the different units.

In scholarly literature there are different points of views on the derived phraseological units that we discuss (Gvozdarev, 1977: 156; Kolesnikova \& Popov 1980; Carter, 2004; Ermakova, 2008 \& Karabulatova, 2014). To our mind, these and the similar correlative pairs undergo more complex changes than only a change in syntactical relations among the components. When it comes to the variation, L.N. Kolesnikova and R.N. Popov mention that some phraseologists do not distinguish between phraseological units patterns and "derivational phenomena very spread in the phraseological system of the Russian language: бить баклуши - битье баклуш, явиться с повинной - явка с повинной» (1980: 9). The authors are sure that it were phraseological units with abstract verbal nouns which were formed on the basis of verbal phraseological units and consider to be not patterns but new derivative phraseological units based on them with not procedural but objective meaning. We share the same opinion and are sure that the derivational structural transformations only in one of the components lead to the phraseological meaning change in the whole phraseological unit.

If we consider a phraseological unit as an integral, but separate in its form, we can claim that derivational formal transformations is to occur in the component of one of the correlative phraseological units but at the same time there should be no quantitative changes in the whole component structure of a phraseological unit.

\section{Conclusion}

To sum up, we suggest terms which are used to describe derivational relations in phraseology. In phraseology the derivation is a processes of formation phraseological units (phraseological derivatives) on the base of phraseological units already existing in a language which are considered to be original and have formal and semantic changes in the derived units nature. In the derived phraseological units, formed on the base of already existing phraseological units, the structural changes expressed by formal means take place. The derivational meaning is a generalized phraseological meaning of the derived units belonging to one class and expressed through their general categorical meaning; the derivational relations are relations of derivation between a productive phraseological unit and a derived one. Derivationally connected units mean an identical logical notion and differ in categorical and subcategorical meaning.

The productive phraseological unit is an initial unit of the Russian phraseological system, on the base of which a new derived unit with a new individual meaning is formed. The derived phraseological unit is a unit of the Russian phraseological system, which is derived from a productive phraseological unit that already exists, with a new individual meaning and which has other functions in the language and speech.

The correlative productive and derived phraseological units differ from each other in belonging the grammatically 
main component to different parts of speech. So the productive phraseological units differ from the derived ones in presence or absence other word-formative affixes. This indicates differences in categorical, subcategorical and individual meanings. Moreover, the correlative phraseological units, involved in derivational relations, have different grammatical features.

Studying the material, we can say that the separate structure of a phraseological unit is not a reason for it not to become a derivative, a productive unit. Thus, one phraseological unit of a correlative pair is the derivational base, which is a productive and motivating unit of the other phraseological unit that is derived and motivated. Besides, the meaning of a derived phraseological unit can be explained only through the meaning of a productive phraseological unit.

The specific character of the derivational relations in phraseology reveals itself, firstly, in the fact that not separate components are involved in the derivation relations but a phraseological unit as a whole as being an integrated language unit (the phraseological component is not independent, it is only a part the phraseological unit, therefore not separate components are involved in the derivation relations but a phraseological unit as a whole as being an integrated language unit), and secondly, the scope of derivation is narrower than in the lexis. At the same time the syntactical and component structure of the correlative phraseological units remain identical. In spite of the fact that the derivational structural transformations occur only in one of the components, it leads to the phraseological meaning change in the whole phraseological unit. The correlative productive and derived phraseological units have the identical logical notion and differ in categorical and subcategorical meaning, because of the difference in belonging the grammatically main component to different parts of speech. The structure and the quantity of the correlated phraseological units remain identical. The grammatically main component of derived phraseological unit, transformed in productive phraseological unit, saves its status and remain the grammatically main component of new derived phraseological unit; any of the derivational means (an affix) is added to the root of the main component.

The most productive derivational relations (631 derivative unites were analysed) present between the procedural and objective phraseological units (99\%): затягивать пояс - "to be short of food" $\rightarrow$ затягивание пояса - "lack of food"; шарахаться из одной крайности в другую - "alternatively to take the extremely different decisions" $\rightarrow$ шараханье из одной крайности в другую - "alternative making extremely different decisions"; толочь воду в ступе - "to do smth useless, to waste time" $\rightarrow$ толчение воды в ступе - "doing smth useless, waste of time" and some others, in which the grammatically main component - the verb - with the affix changes its belonging to other parts of speech in the productive phraseological unit.

The structural changes in the verbal component into the noun are produced by the affixation (with marked or unmarked suffix). The most productive formation of the derivatives uses the suffixes -ениј-, -ниј-, аниј-, -к-, -тиј-, -тель-, -ость-, -б-, -ств-, -ежк-, -ок- (Ermakova 2008: 16). With these suffixes 93\% of the alalysed objective phraseological units were formed. The most productive suffix of these suffixed is -ениј-(50\% of the derived objective phraseological derivatives were formed when the verbal component is changed and with this suffix from the stem of verbal component with the ending -и- or from the stems ended on the consonant): сводить счеты $\rightarrow$ сведение счетов, бить в грудь $\rightarrow$ биение в грудь, коптить небо $\rightarrow$ копчение неба, выносить/вынести сор из избы $\rightarrow$ вынесение сора из избы. With the suffix -ниј- (-ньј-) 35\% of all phraseological derivatives were formed: блуждать потемках $\rightarrow$ блуждание в потемках, кататься как сыр в масле $\rightarrow$ катание как сыр в масле, вилять хвостом $\rightarrow$ виляние хвостом. $7 \%$ of the objective phraseological units were formed with the suffix -тиj- from the stems of indefinite form of objective verbs: открывать/открыть Америку $\rightarrow$ открытие Америки, шить дело $\rightarrow$ шитье дела, бить в грудь $\rightarrow$ битье в грудь, снимать/снять шкуру $\rightarrow$ снятие шкуры. The formation of objective phraseological units from the productive procedural with other suffixes occur much more rarely.

In the contemporary Russian language, the phrase formation is a dynamic process, which maintains the constant internal development of the phraseological system. The derived phraseological units - derivatives - enrich the semantic categories of the object that leads to enhancement of the nominative system of a language.

\section{Acknowledgement}

This work done under the grant of the President of the Russian Federation for the state support of young Russian scientists - PhD (Contract № 14.Z56.15.5221-MC on the conditions of use of the grant of the President of the Russian Federation for the state support of young Russian scientists and organizations - participants of the competition, having an employment relationship with young scientists MK-5221.2015.6 of 16 February 2015). 


\section{References}

Avaliani, Yu.Yu. (1975) O vtorichnoy frazeologicheskoy derivatsii. K voprosu o razvitii frazeologicheskoy sistemy russkogo yazyka // Problemy russkoy frazeologii. Tula. pp. 7-13.

Bushuy, A.M. (1980) K izucheniyu derivatsionnykh protsessov vo frazeologii (na materiale russkogo yazyka) // Problemy frazeologii. Tula. pp. 53-59.

Gvozdarev, Yu.A. (1977) Osnovy russkogo frazoobrazovaniya. Rostov-n/D. pp. 184.

Ermakova, E.N. (2008) Frazo- i slovoobrazovanie v sfere frazeologii: avtoref. dis. d-rafilol. nauk. Tyumen. pp. 41.

Kolesnikova, L.N. \& Popov R.N. (1980) K voprosu o variantnosti frazeologicheskih yedinits // Problemy frazeologii. Tula. pp. 3-13.

Teliya, V.N. (1973) O tipakh i sposobakh frazoobrazovanija // Problemy russkogo frazoobrazovanija. Tula. pp. 25-43.

Cowie, (2001) - Anthony Paul Cowie. Phraseology: Theory, Analysis, and Applications. Oxford University Press. pp. 258.

Carter, R. (2004) Language and Creativity: The Art of Common Talk. Routledge. pp.: 255.

Gilazov, T.Sh, Karabulatova I.S., Sayfulina F.S. \& Kurakova Ch.M. (2015) Between the East and the West: Phenomenon of Tartar Literary Criticism in the Lingvo-Cultural Aspect. In the: Mediterranean Journal of Social Science. 2015. Vol 6, No3, S2. pp. 524533.

Karabulatova, I.S. (2013) The problems of linguistic modeling of new Eurasian linguistic personality in multilinguistic and mental environment (by example of onomasphere) // Middle-East Journal of Scientific Research 17 (6): 791-795.

Karabulatova, I.S. \& Polivara Z.V. (2013) Turkic and Slavs: bi-polylinguism in globalization and migrations (on an example of Tumen region) // Middle-East Journal of Scientific Research 17 (6): 832-836.

Karabulatova, I.S., Sayfulina F.S. \& Ahmetova B.Z. (2013) Ethno-lingual aspect of modern functioning of Russian dialects in North Kazakhstan (on an example of Kostanai region) // World Applied Sciences Journal Issue 27 (Education, law, economics, language and communication): 137-140.

Karabulatova, I.S. \& Zinchenko A.A. (2014) Tyumen Nenets Sacral Childhood Culture as an Ethnolinguistic Mechanism of Preserving Ethnic Identity. In the: Middle-East Journal of Scientific Research 20 (11): 1344-1347.

Karabulatova, I.S., Ermakova E.N. \& Chiganova G.A. (2014) Astana in Kazakhstan and Astana in Siberia as a form of national Islam of Eurasia in the linguistic-cultural aspect// Terra Sebus: Acta Musei Sabesiensis, Special Issue. pp. 15-30.

Karabulatova, I.S. \& Sayfulina F.S. (2015) Mytholinguistic Interpretation of Sacral Toponym Astana in Sociocultural Practice of the Siberian Tatars. In the: Asian Social Science, 2015, Vol11, No 5, pp.: 303-310.

Karabulatova, I.S. (2014) Problema obrazovaniya novykh frazeologizmov v regionalnoy russkoy yazykovoy kul'ture // Vestnik Novgorodskogo gosudarstvennogo universiteta. № 83, ch.1. pp. 81-84.

Karabulatova, I.S., Khachmafova Z.R., Bricheva M.M., Nescheretova M.T. \& Bersirova A.K. (2015) Linguopragmatic Aspect of "Search for the Ideal" in the Discourse of Female Fiction as a Reflection of Matrimonial-Demographic and Sexual Behavior in Contemporary Russian Society. Review of European Studies. 2015. Vol. 7. No 6. pp.: 35-45.

Karabulatova, I.S. \& Polivara Z.V. (2015) Intraethnic installation of Ukrainian Labour migtants in the preservation of linguistic and cultural identity. In the: Mediterranean Journal of Social Science. Vol 6, No3, S2, p. 142-148.

Lomakina, O.V. (2014) Inoyazychnaya frazeologiya i paremiologiya v tekstakh L.N.Tolstogo: osobennosti pereklyucheniya yazykovogo koda // Vestnik Cherepovetskogo gosudarstvennogo universiteta, Cherepovets. №7(60). pp. 93-96.

Nikolaeva E.A. Pervichnoe frazoobrazovanie v bel'giyskom variante frantsuzskogo yazyka: semanticheskiy aspect. Diss. kand.filol.n. M.: MPGU, 2006. - $304 \mathrm{~s}$.

Ryazantsev, S.V., Pismennaya E.E., Karabulatova I.S. \& Charif Y. Akramov. (2014) Transformation of sexual and matrimonial behavior of Tajik labor migrants in Russia // Asian Social Science. Vol 10, No.20.

Sayfulina, F.S. \& Karabulatova I.S. (2014) European studies of Barabin Tatar folklore: the role of investigations of the German scientist V.V. Radlov // Life Science Journal 4; 11 (9s): 116-119.

Skandera, P. (2007) Phraseology and Culture in English. Mouton de Gruyter. pp.: 511.

Zamaletdinov, R.R., Karabulatova I.S., Yarmakeev I.E. \& Ermakova E.N. (2014) Linguo-propaedeutics of ethnic conflicts as a basis for stability in complex Polyethnic regions// Asian Social Science. Vol.10, No.20. pp. 164-173. 